\title{
RANCANG BANGUN TURBIN ANGIN POROS HORIZONTAL TIGA SUDU FLAT BERLAPIS TIGA DENGAN VARIASI SUDUT DAN POSISI SUDU
}

\author{
Sahid , Slamet Priyoatmojo \\ Program Studi Teknik Konversi Energi, Jurusan Teknik Mesin, Politeknik Negeri Semarang \\ Email : sahid@polines.ac.id
}

\begin{abstract}
Abstrak
Tujuan tugas akhir rancang bangun turbin angin poros horizontal tiga sudu flat berlapis tiga dengan variasi sudut dan posisi sudu adalah untuk mengkaji secara eksperimental kinerja turbin angin tiga sudu flat tiga lapis dengan berbagai macam variasi sudut blade, variasi kecepatan angin dan variasi posisi sudu untuk mendapatkan nilai efisiensi sistem terbaik. Metode yang dilakukan adalah merancang desain turbin angin dengan 3 posisi berbeda yang sudutnya dapat divariasikan. Posisi pertama yaitu dengan jarak antar sudu $50 \mathrm{~mm}$, posisi kedua yaitu dengan jarak antar sudu $40 \mathrm{~mm}$ dan posisi ketiga yaitu dengan jarak antar sudu $30 \mathrm{~mm}$. Selanjutnya membuat alat-alat utama maupun pendukung pada turbin angin, merakit alat-alat tersebut dan melakukan pengujian turbin angin. Data pengujian yang dibutuhkan berupa kecepatan angin di depan turbin (Vr), luas sapuan turbin (A), putaran poros (n), tegangan (V) dan arus (I). Hasil pengujian yang didapatkan pada posisi 1 untuk kecepatan angin $6 \mathrm{~m} / \mathrm{s}, 7 \mathrm{~m} / \mathrm{s}, 8 \mathrm{~m} / \mathrm{s}$ dan $9 \mathrm{~m} / \mathrm{s}$ mencapai efisiensi tertinggi pada sudut $25^{\circ}$ yaitu 3,158\%, 4,08\%, 4,4\% dan 3,298\%. Pada posisi 2 untuk kecepatan angin $6 \mathrm{~m} / \mathrm{s}, 7 \mathrm{~m} / \mathrm{s}, 8 \mathrm{~m} / \mathrm{s}$ dan $9 \mathrm{~m} / \mathrm{s}$ mencapai efisiensi tertinggi pada sudut $20^{\circ}$ yaitu 3,23\%, 4,27\%, 4,883\% dan 3,815\%. Pada posisi 3 untuk kecepatan angin $6 \mathrm{~m} / \mathrm{s}, 7 \mathrm{~m} / \mathrm{s}, 8 \mathrm{~m} / \mathrm{s}$ dan 9 $\mathrm{m} / \mathrm{s}$ mencapai efisiensi tertinggi pada sudut $20^{\circ}$ yaitu $3,197 \%, 4,226 \%$, 3,968\% dan 3,262\%.
\end{abstract}

Kata kunci : variasi sudut, posisi sudu, efisiensi sistem

\section{Pendahuluan}

Angin sebagai sumber energi yang jumlahnya melimpah merupakan sumber energi yang terbarukan dan tidak menimbulkan polusi udara karena tidak menghasilkan gas buang yang dapat menyebabkan efek rumah kaca. Indonesia memiliki potensi energi angin yang sangat besar yaitu sekitar 9,3 GW dan total kapasitas yang baru terpasang saat ini sekitar 0,5 MW (Daryanto, 2007). Salah satu pemanfaatan energi angin adalah dengan menggunakan turbin angin. Turbin angin mampu mengubah energi kinetik angin menjadi energi listrik dengan bantuan generator.

\section{Tujuan Teknis}

Tujuan teknis dari pembuatan Tugas Akhir iniyaitu :

1. Membuat turbin angin poros horizontal tiga sudu flat berlapis tiga dengan variasi sudut dan posisi sudu.
2. Menganalisa karakteristik kerja turbin angin poros horizontal tiga sudu flat berlapis tiga dengan variasi sudut dan posisi sudu yang bervariasi sehingga mendapatkan nilai efisiensi sistem.

\section{Tinjauan Pustaka}

Potensi energi angin di Indonesia umumnya berkecepatan lebih dari $5 \mathrm{~m} / \mathrm{s}$ pada ketinggian pusat $10 \mathrm{~m}$. Berdasarkan data Blueprint Energi Nasional, Departemen ESDM RI bahwa potensi Pembangkit Listrik Tenaga Bayu (PLTB) di Indonesia menarik untuk dikembangkan, dari potensi sebesar 9,29 GW hanya sekitar 0,5 GW yang baru dikembangkan. Hal ini menyiratkan bahwa prospek pengembangan teknologi ini masih tinggi sehingga dapat dilakukan penelitian dan pengembangan di beberapa wilayah di Indonesia yang dapat berkontribusi besar terhadap penggunaan PLTB (Daryanto, 2007). Tabel 2.1 merupakan data kondisi angin tiap kelas angin. 
Tabel 2.1 Kondisi Angin

\begin{tabular}{|c|c|c|c|}
\hline $\begin{array}{c}\text { Kelas } \\
\text { Angin }\end{array}$ & $\begin{array}{c}\text { Kecepatan } \\
\text { Angin m/s }\end{array}$ & $\begin{array}{c}\text { Kecepatan } \\
\text { Angin } \\
\text { km/jam }\end{array}$ & $\begin{array}{c}\text { Kecepatan } \\
\text { Angin } \\
\text { knot/jam }\end{array}$ \\
\hline 1 & $0 . .3-1.5$ & $1-5.4$ & $0.58-2.92$ \\
\hline 2 & $1.6-3.3$ & $5.5-11.9$ & $3.11-6.42$ \\
\hline 3 & $3.4-5.4$ & $12-19.5$ & $6.61-10.5$ \\
\hline 4 & $5.5-7.9$ & $19.6-28.5$ & $10.7-15.4$ \\
\hline 5 & $8-10.7$ & $28.6-38.5$ & $15.6-20.8$ \\
\hline 6 & $10.8-13.8$ & $38.6-49.7$ & $21-26.8$ \\
\hline 7 & $13.9-17.1$ & $49.8-61.5$ & $27-33.3$ \\
\hline 8 & $17.2-20.7$ & $61.6-74.5$ & $33.5-40.3$ \\
\hline 9 & $20.8-24.4$ & $74.6-87.9$ & $40.5-47.5$ \\
\hline 10 & $24.4-28.4$ & $88-102.3$ & $47.7-55.3$ \\
\hline 11 & $28.5-32.6$ & $102.4-117$ & $55.4-63.4$ \\
\hline
\end{tabular}

Turbin angin merupakan suatu alat dengan sudu berputar dimana mekanisme kerjanya adalah memanfaatkan energi angin dan mengubahnya ke dalam bentuk energi gerak putaran poros untuk menghasilkan energi listrik.

\section{Jenis-Jenis Turbin Angin}

Pengelompokkan turbin angin berdasarkan prinsip aerodinamik pada rotor yaitu apakah rotor turbin angin mengekstrak energi angin memanfaatkan gaya drag dari aliran udara yang melalui sudu rotor atau rotor angin mengekstrak energi angin atau dengan memanfaatkan gaya lift yang dihasilkan oleh aliran udara melalui profil aerodinamik sudu. Kedua prinsip aerodinamik yang dimanfaatkan turbin angin memiliki perbedaan putaran pada rotornya, gaya drag memiliki putaran rotor relatif rendah dibandingkan turbin angin yang rotornya menggunakan prinsip gaya lift. Jika dilihat dari arah sumbu rotasi rotor, turbin angin dapat dibagi menjadi dua bagian yaitu:

1. Turbin Angin Sumbu Vertikal (TASV)

2. Turbin Angin Sumbu Horizontal (TASH)

\section{Turbin Angin Sumbu Vertikal (TASV)}

Turbin angin sumbu vertikal/tegak (TASV) merupakan turbin angin yang sumbu putarnya tegak lurus dengan arah aliran angin atau permukaan tanah (Arwoko, 1999). Kelebihan turbin ini yaitu memiliki torsi tinggi sehingga dapat berputar pada kecepatan angin rendah, cocok dioperasikan pada daerah yang berkecepatan rendah-sedang. Dilihat dari prinsip aerodinamik rotor yang digunakan, turbin angin sumbu vertikal dibagi menjadi dua bagian yaitu:

A. Savonius Rotor

Turbin ini memiliki rotor dengan bentuk dasar setengah silinder. Konsep turbin angin savonius cukup sederhana, prinsip kerjanya memanfaatkan gaya $\mathrm{drag}$.

\section{B. Darrieus Rotor}

Turbin ini memiliki efisiensi terbaik serta mampu menghasilkan torsi cukup besar pada putaran dan kecepatan angin yang tinggi. Turbin angin Darrieus mengaplikasikan blade dengan bentuk dasar airfoil NACA. Prinsip kerja turbin angin Darrieus yaitu memanfaatkan gaya lift.

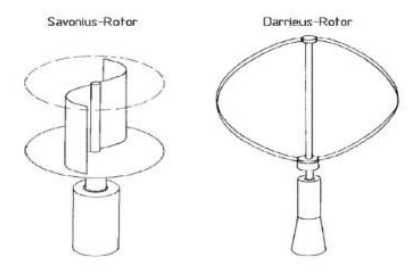

\section{Gambar 2.1 Jenis-Jenis Turbin Angin} Sumbu Vertikal

(Sumber: Erich Hau, 2006)

\section{Turbin Angin Sumbu Horizontal (TASH)}

Turbin angin sumbu horizontal merupakan turbin angin yang mempunyai sumbu putar yang terletak sejajar dengan permukaan tanah dan sumbu putar rotor yang searah dengan arah angin (Arwoko, 1999). Pada turbin ini, putaran rotor terjadi karena adanya gaya lift. Turbin ini cocok digunakan pada tipe angin sedang dan tinggi dan banyak digunakan sebagai pembangkit listrik skala besar.

Kelebihan dari turbin angin sumbu horizontal memiliki efisiensi yang lebih tinggi dibandikan dengan sumbu vertikal karena sudu selalu bergerak tegak lurus terhadap arah angin. Sedangkan kekurangannya adalah dibutuhkan 
konstruksi tower yang besar dan tinggi, membutuhkan kontrol sebagai mekanisme untuk mengarahkan blade ke arah angin.

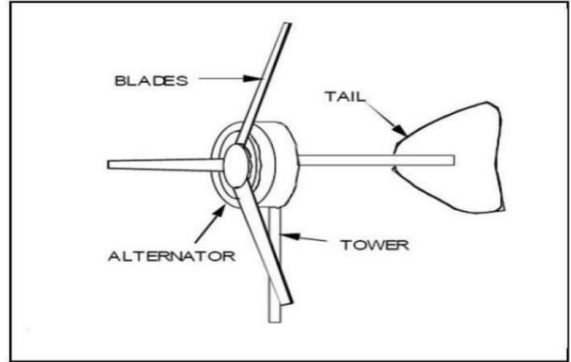
Horizontal

(Sumber: Hugh Piggot, 2003)

Tipe-tipe turbin angin sumbu horizontal dibedakan menjadi 2 menurut letak rotor dan jumlah sudu yang digunakan.

1. Menurut letak rotor, turbin angin sumbu horizontal dibedakan menjadi 2 antara lain sebagai berikut :

a. Upwind Turbine

Turbin Upwind merupakan jenis turbin angin sumbu horizontal yang memiliki rotor yang menghadap arah datangnya angin.

\section{b. Downwind Turbine}

Turbin Downwind merupakan suatu turbin yang letak rotornya membelakangi arah

datangnya angin.
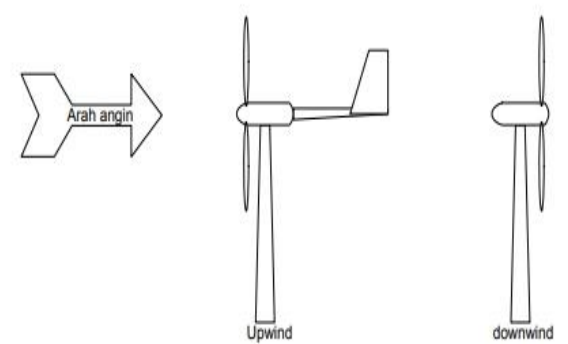

Gambar 2.3 Turbin Angin jenis Upwind dan Downwind

(Sumber: Matthew, 2006)

2. Menurut jumlah sudu yang digunakan, turbin angin sumbu horizontaldibedakan menjadi 4 antara lain sebagai berikut :

a. Turbin angin satu sudu (single blade)

Keadaan turbin angin akan sulit setimbang dan turbin angin membutuhkan angin yang sangat kencang untuk dapat memutar turbin.

b. Turbin angin dua sudu (double blade)

Turbin angin ini akan lebih mudah untuk setimbang dibandingkan jumlah satu sudu tetapi masih ada kemungkinan untuk bergeser.

c. Turbin angin tiga sudu (three blade)

Turbin angin dengan konsep ini lebih mudah setimbang dibandingkan jumlah satu sudu dan dua sudu serta memiliki kemampuan menangkap angin yang efektif.

d. Turbin angin banyak sudu (multi blade)

Turbin angin dengan konsep banyak sudu menghasilkan momen gaya awal yang besar, mampu digunakan pada kecepatan angin rendah. Pada umumnya memiliki sudu yang pipih dengan kelengkungan yang halus serta memiliki konstruksi yang solid.

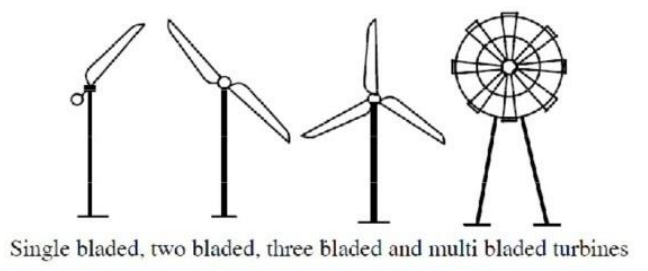

Gambar 2.4 Tipe Turbin Angin

Berdasarkan Jumlah Sudu

(Sumber: Matthew, 2006)

\section{Hasil Dan Pembahasan}

Rancangan turbin angin tiga sudu flat berlapis tiga yang telah dibuat dapat dilihat pada gambar 4.1

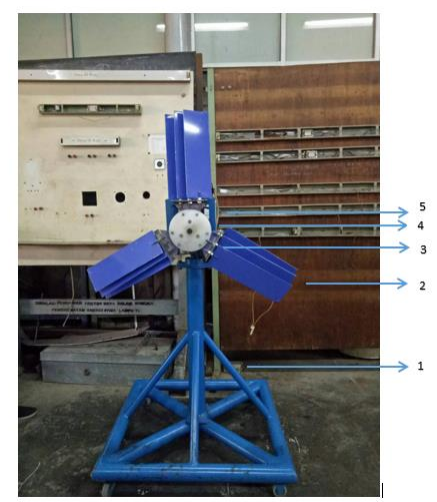

Gambar 4.1 Turbin Angin Tiga Sudu Flat Berlapis Tiga 
Komponen utama turbin angin terdiri dari beberapa bagian: (1) Kerangka bawah; (2) Sudu; (3) Dudukan sudu; (4) Piringan sudu; (5) Kerangka atas.

\section{Data Hasil Pengujian}

Data hasil pengujian diperoleh dari pengujian yang telah dilakukan di Laboratorium Teknik Konversi Energi dan dapat dilihat pada Tabel 4.1. Data yang diperoleh merupakan data yang dibutuhkan dalam menganalisis kinerja turbin angin. Data tersebut antara lain kecepatan angin bebas (vbebas), luas sapuan turbin (A), putaran poros (n), kecepatan angin di depan turbin (vr), beban (R), tegangan (V) dan arus (I). Data pada tabel 4.1 merupakan data hasil pengujian turbin angin poros horizontal tiga sudu flat berlapis tiga dengan sudut dan posisi terbaik yaitu pada posisi 2, sudut $20^{\circ}$ serta kecepatan angin bebas 8 $\mathrm{m} / \mathrm{s}$. Untuk data pengujian variasi yang lain dapat dilihat pada lampiran 5 .

Tabel 4.1 Data Hasil Pengujian Turbin Angin Poros Horizontal TigaSudu Flat Berlapis Tiga pada Posisi 2, Sudut sudu $20^{\circ}$ dan Kecepatan Angin Bebas 8 m/s.

\begin{tabular}{|c|c|c|c|c|c|c|c|c|}
\hline No. & $\begin{array}{c}\rho \\
\text { Udara }\end{array}$ & $\begin{array}{c}\mathbf{r} \\
(\mathbf{m})\end{array}$ & $\begin{array}{c}\text { Beb } \\
\text { an } \\
(\mathbf{W})\end{array}$ & $\begin{array}{c}\text { Putaran } \\
(\mathbf{r p m})\end{array}$ & $\begin{array}{c}\text { vbebas } \\
(\mathbf{m} / \mathbf{s})\end{array}$ & $\begin{array}{c}\mathbf{v r} \\
(\mathbf{m} / \\
\mathbf{s})\end{array}$ & $\begin{array}{c}\text { Tega } \\
\text { ngan } \\
(\mathbf{v})\end{array}$ & $\begin{array}{c}\text { Arus } \\
(\mathbf{A})\end{array}$ \\
\hline 1 & 1.221 & 0.425 & 0 & 320 & 8 & 7.32 & 17 & 0 \\
\hline 2 & 1.221 & 0.425 & 5 & 284 & 8 & 7.32 & 14 & 0.24 \\
\hline 3 & 1.221 & 0.425 & 10 & 252 & 8 & 7.32 & 10 & 0.39 \\
\hline 4 & 1.221 & 0.425 & 15 & 193 & 8 & 7.32 & 9 & 0.6 \\
\hline 5 & 1.221 & 0.425 & 20 & 184 & 8 & 7.32 & 8.3 & 0.74 \\
\hline 6 & 1.221 & 0.425 & 25 & 128 & 8 & 7.32 & 6.9 & 0.78 \\
\hline 7 & 1.221 & 0.425 & 30 & 120 & 8 & 7.32 & 6.3 & 0.8 \\
\hline 8 & 1.221 & 0.425 & 35 & 119 & 8 & 7.32 & 6 & 0.82 \\
\hline 9 & 1.221 & 0.425 & 40 & 110 & 8 & 7.32 & 5.6 & 0.84 \\
\hline 10 & 1.221 & 0.425 & 45 & 107 & 8 & 7.32 & 5.4 & 0.85 \\
\hline 11 & 1.221 & 0.425 & 50 & 107 & 8 & 7.32 & 5.1 & 0.86 \\
\hline 12 & 1.221 & 0.425 & 55 & 105 & 8 & 7.32 & 4.5 & 0.87 \\
\hline 13 & 1.221 & 0.425 & 60 & 104 & 8 & 7.32 & 3.7 & 0.9 \\
\hline 14 & 1.221 & 0.425 & 65 & 95 & 8 & 7.32 & 3.3 & 0.93 \\
\hline 15 & 1.221 & 0.425 & 70 & 92 & 8 & 7.32 & 2.5 & 0.95 \\
\hline
\end{tabular}

Data pada tabel 4.1 selanjutnya digunakan untuk menghitung Daya Kinetik (Pkin), Daya Generator (Pgen) dan Efisiensi sistem menggunakan persamaan 3.2 sampai 3.3. Contoh perhitungan diambil pada tabel 4.1 No.5 dengan data sebagai berikut :

1. Kecepatan angin di depan sudu = $7,32 \mathrm{~m} / \mathrm{s}$

2. Putaran turbin $(\mathrm{n}) \quad=184 \mathrm{rpm}$

3. $\rho$ udara $=\quad 1,221$

$\mathrm{kg} / \mathrm{m}^{3}$ (lampiran 1)

4. Jari-jari turbin

$0.425 \mathrm{~m}$

5. Tegangan $(\mathrm{V})$

Volt
6. Arus (I)
$=\quad 0,74$

Ampere

Data diatas kemudian dihitung dengan menggunakan persamaan sebagai berikut : Perhitungan luas sapuan turbin sesuai dengan persamaan (3.1), yaitu :

$$
\mathrm{A} \quad \begin{aligned}
& =\pi \times r^{2} \\
& =\pi \times 0.425^{2} \\
& =0.567 \mathrm{~m}^{2}
\end{aligned}
$$

Perhitungan daya kinetik sesuai dengan persamaan (3.2), yaitu :

Pkin $=\frac{1}{2} \cdot$ pudara.A. $V^{3}$

$$
\begin{aligned}
& =\frac{1}{2}(1,221)(0,567)(7,32)^{3} \\
& =125,76 \text { Watt }
\end{aligned}
$$

Perhitungan Daya Generator sesuai dengan persamaan (3.4), yaitu :

Pgen $=$ V.I

$$
\begin{aligned}
& =8 \times 0,74 \\
& =6,142 \mathrm{Watt}
\end{aligned}
$$

Perhitungan Efisiensi sistem sesuai dengan persamaan (3.5), yaitu :

$$
\begin{aligned}
\eta_{s}= & \frac{\text { Pgen }}{\text { Pkin }} \times 100 \% \\
& \frac{6,142}{125,76} \times 100 \% \\
= & 4.88 \%
\end{aligned}
$$




\section{Karakteristik Efisiensi Sistem Terhadap Kecepatan Angin Untuk Posisi Terbaik}

Selain mendapatkan sudut dan kecepatan terbaik, hasil pengujian yang dilakukan juga mendapatkan posisi sudu terbaik yang menghasilkan efisiensi tertinggi. Gambar 4.8 dibawah adalah grafik yang menunjukkan posisi sudu terbaik untuk kecepatan $6 \mathrm{~m} / \mathrm{s}, 7 \mathrm{~m} / \mathrm{s}, 8 \mathrm{~m} / \mathrm{s}$ dan $9 \mathrm{~m} / \mathrm{s}$.

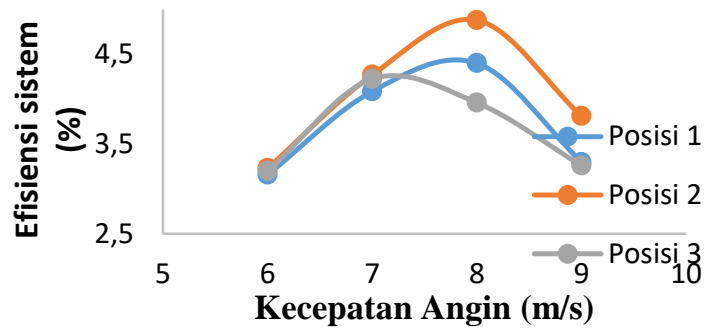

Gambar 4.8 Karakteristik Posisi Sudu Terbaik Turbin Terhadap Kecepatan Angin

Gambar 4.8 adalah kurva karakteristik posisi sudu terbaik terhadap kecepatan angin $6 \mathrm{~m} / \mathrm{s}, 7 \mathrm{~m} / \mathrm{s}, 8 \mathrm{~m} / \mathrm{s}$ dan $9 \mathrm{~m} / \mathrm{s}$. Berdasarkan gambar 4.8 terbukti bahwa puncak-puncak efisiensi dipengaruhi oleh kecepatan angin. Posisi sudu terbaik yang menghasilkan nilai efisiensi tertinggi terjadi pada saat posisi 2. Hasil pengujian posisi 1 dan posisi 3 lebih rendah dibandingkan dengan posisi 2. Pada posisi 1 dan 2 titik puncak terjadi ketika kecepatan angin $8 \mathrm{~m} / \mathrm{s}$ sedangkan pada posisi 3 titik puncak terjadi ketika kecepatan angin $7 \mathrm{~m} / \mathrm{s}$.

\section{Analisis Kinerja Turbin}

Pengujian dan pengolahan data bertujuan untuk mengetahui karakteristik dari turbin angin melalui putaran dan efisiensi. Efisiensi dipengaruhi oleh daya kinetik (Pkin) dan daya generator (Pgen). Daya kinetik (Pkin) memiliki nilai yang konstan pada setiap kecepatan angin bebas yang diuji. Daya generator (Pgen) dipengaruhi oleh nilai tegangan dan arus yang dihasilkan. Dari hasil pengujian dapat dilihat bahwa kurva terjadi akibat efisiensi sistem yang sudah mencapai titik puncak akan mengalami penurunan.

Berdasarkan data hasil pengujian pada posisi 1 didapatkan hasil pengujian untuk kecepatan angin $6 \mathrm{~m} / \mathrm{s}, 7 \mathrm{~m} / \mathrm{s}, 8 \mathrm{~m} / \mathrm{s}$ dan $9 \mathrm{~m} / \mathrm{s}$ mencapai efisiensi tertinggi pada sudut $25^{\circ}$ yaitu $3,158 \%, 4,08 \%$, $4,4 \%$ dan 3,298\%. Pada posisi 2 didapatkan hasil pengujian untuk kecepatan angin $6 \mathrm{~m} / \mathrm{s}, 7 \mathrm{~m} / \mathrm{s}, 8 \mathrm{~m} / \mathrm{s}$ dan 9 $\mathrm{m} / \mathrm{s}$ mencapai efisiensi tertinggi pada sudut $20^{\circ}$ yaitu $3,23 \%, 4,27 \%, 4,883 \%$ dan $3,815 \%$. Pada posisi 3 didapatkan hasil pengujian untuk kecepatan angin 6 $\mathrm{m} / \mathrm{s}, 7 \mathrm{~m} / \mathrm{s}, 8 \mathrm{~m} / \mathrm{s}$ dan $9 \mathrm{~m} / \mathrm{s}$ mencapai efisiensi tertinggi pada sudut $20^{\circ}$ yaitu $3,197 \%$, 4,226\%, 3,968\% dan 3,262\%. Berdasarkan data hasil pengujian yang didapatkan diketahui bahwa turbin angin tiga sudu flat berlapis tiga baik digunakan ketika menggunakan posisi 2 yang kecepatan anginnya $8 \mathrm{~m} / \mathrm{s}$ dan sudut sudunya $20^{\circ}$.

Ketika mengacu pada hasil pengujian posisi 1, 2 dan 3. Efisiensi sistem terbaik dicapai ketika posisi sudu berada di posisi 2. Hal itu disebabkan karena ketika jarak antar sudu semakin besar maka sudut yang dibutuhkan sudu harus besar sehingga usaha buangan angin sudu besar. Sedangkan ketika jarak antar sudu semakin kecil, sudut yang dibutuhkan sudu harus semakin rapat sehingga buangan angin akan semakin keras ketika menumbuk sudu.

\section{Kesimpulan}

1. Data pengujian yang dibutuhkan berupa kecepatan angin di depan turbin (Vr), luas sapuan turbin (A), putaran poros $(\mathrm{n})$, tegangan $(\mathrm{V})$ dan arus (I).

2. Hasil pengujian yang didapatkan pada posisi 1 untuk kecepatan angin $6 \mathrm{~m} / \mathrm{s}$, $7 \mathrm{~m} / \mathrm{s}, 8 \mathrm{~m} / \mathrm{s}$ dan $9 \mathrm{~m} / \mathrm{s}$ mencapai efisiensi tertinggi pada sudut $25^{\circ}$ yaitu $3,158 \%, 4,08 \%, 4,4 \%$ dan 
3,298\%. Pada posisi 2 untuk kecepatan angin $6 \mathrm{~m} / \mathrm{s}, 7 \mathrm{~m} / \mathrm{s}, 8 \mathrm{~m} / \mathrm{s}$ dan $9 \mathrm{~m} / \mathrm{s}$ mencapai efisiensi tertinggi pada sudut $20^{\circ}$ yaitu $3,23 \%, 4,27 \%$, $4,883 \%$ dan $3,815 \%$. Pada posisi 3 untuk kecepatan angin $6 \mathrm{~m} / \mathrm{s}, 7 \mathrm{~m} / \mathrm{s}, 8$ $\mathrm{m} / \mathrm{s}$ dan $9 \mathrm{~m} / \mathrm{s}$ mencapai efisiensi tertinggi pada sudut $20^{\circ}$ yaitu $3,197 \%, \quad 4,226 \%, \quad 3,968 \%$ dan $3,262 \%$.

\section{Daftar Pustaka}

Gupta R, Roy S, and Biswas A. 2010. Computational Fluid Dynamics of Twisted Airfoil Shaped Two Bladed H-Darrieus Rotor Made From Fibreglass Reinforced Plastic (FRP). International Journal of Energy and Environment. Vol. 1. Pp. 953-968

Leysen E.H. 1983, Introduction to Wind Energy. PO BOX 85/Amersfort/The Netherlands: Steering Committee Wind Energy, Developing Countries

Soelaiman, Fauzi TA., Tandian NP., Rachmatulloh Rizki. 2010. Optimasi Penambahan Selubung (Shroud) pada Turbin Angin Sumbu Vertikal dengan Menggunakan Simulasi CFD 2 Dimensi. SNTTM ke-9 Palembang.

Sabzevari, A. 2007. Power Augmentation in a Ducted Savonius Rotor. Pahlavy University, Iran. Second Int. Symposium Wind Energy Systems. BHRAFluid. 